portions which depend on the metal used and the temperature and concentration of the acid. The complete analysis of such a mixture is both difficult and tedious. In the case of iron, however, the last three of the gaseous products just mentioned have not been detected, and the chief products requiring estimation are nitrogen peroxide, nitric oxide, nitrogen, and ammonia.

The authors describe a method of collecting and analysing the gases yielded by a 0.30 gram sample dissolved at $100^{\circ} \mathrm{C}$. Under these conditions they assume that the whole of the iron is ultimately converted into ferric nitrate. They discuss the primary and secondary reactions which they consider occur; and, in particular, the interchangeability of nitrogen and ammonia with nitric oxide and nitrogen peroxide is shown. They find that the reaction of pure iron undergoes an almost discontinuous change at a certain acid strength (about 24 grams per Ioo c.c.), and that much of the nitrogen and ammonia is replaced by nitric oxide and nitric peroxide as the acid strength increases from 23 to 25 . These are the two main groups of products, and they find that the ratio between the iron equivalents given by the two groups is approximately independent of the secondary reaction between the members of each group. By plotting as ordinate the weight of iron consumed in forming nitrogen and ammonia, and as abscissa the acid strength in grams per Ioo c.c., a characteristic curve is obtained which they term "the reaction curve," and this expresses the principal feature of the reaction.

In the second part of their investigation the authors examined in several typical cases the relation between the reaction curve and the degree of strain in the sample, and found that the curves are always shifted to the right with increase in strain. Wires deformed by twisting yielded progressively advancing reaction curves, and measurable changes in the gas analyses were found to be produced by an amount of energy which, if developed as heat, would not raise the temperature of the material ${ }^{\circ} \mathrm{C}$. Similar curves were obtained with drawn wires. The results are interpreted by the authors as indicating that cold working takes places in two stages: (I) The elastically stressed crystals are brought into an interlocked condition; and $(2)$ the crystal structure is then progressiveli: broken up with the production of amorphous material.

The method has been used by the authors to investigate the removal of cold work from iron by heat treatment, and in the case of the sample used it was found to be complete at $520^{\circ} \mathrm{C}$. The results described are of considerable interest, and the method appears to be one of decided promise.

H. C. H. C.

\section{THE MINISTRY OF HEALTH BILL.}

THE text of the Ministry of Health Bill, already 1 noted as having been presented to the House of Commons on February $\mathbf{I}$, has since been published. As foreshadowed br Dr. Addison in his speech to the members of the Medical P'arliamentary Committee, prior to its introduction, the Bill differs little from the measure originally presented to the last Parliament. That it does differ to some extent, however, particularly in bearing signs of having been worked at and polished, is worthy of mention. The new Bill carries the stamp of finality, and suggests that most of the State Departments performing health functions - the Local Government Board, the Board of Education, and the Insurance Commissioners especially-have arrived at arrangements more or less agreeable to all parties. The position as between the two first-named, for example, is shown to be fairly easy. Even as regards the place to be taker by the Insurance Commissioners, there is less reason for dissatisfaction, and concessions no doubt have been made by the various bodies and individuals concerned. Speaking generally, the measure is a hopeful one, and inspires the feeling that we are well on the way to the establishment of the Ministry. The tone adopted by Dr. Addison is significant of this also, as is the translation of Sir George Newman to the Local Government Board, and the granting to him of the title of "Chief Medical Officer," with the status of a Secretary of the Board.

One part of the Bill which has been carried over unaltered from its predecessor is that relating to the appointment of consultative committees, and Dr. Iddison, by his utterances, has shown himself to be firmly wedded to this idea, and expectant of results of great value from the work to be done by these bodies. Doubtless he has every right to be hopeful. The Consumers' Council at the Ministry of Food, which mav be regarded as more or less analogous, though it was occasionally snecred at, must have assisted the Food Controller considerably. There is no reason to suppose that the Ministry of Health consultative committees will be any less heipful. Indeed, since they are to consist of carefully selected experts on matters having a bearing on national health, they are almost bound to be more valuable. In any event, the consultative committer idea has this to rocommend it: that it will popularise health work. The committees will serve as a most effective link between the Department doing the work and those for whose benefit the work is done. The Department and the workers will be less cloistered; the workers and those who are worked for will be more intimately associated. The public will see and hear of what is being done, and will come to recognise the necessity for assisting in, and taking advantage of, the efforts made. So far there have been remarkably few comments on the Bill, but on the whole the reception has been entirely favourable.

\section{FORTHCOMING BOOKS OF SCIENCE.}

\section{Agriculture and Horticulture.}

A. and C. Black, Ltd.-Black's Gardening Dictionary, edited by E. T. Ellis. Macmillan and Co., Ltd.-Science and Fruit Growing: Being an Account of the Results obtained at the Woburn Experimental Fruit Farm since its Foundation in 1894 , the Duke of Bedford and S. Pickering. John Murray.-Hints to Farm Pupils, E. W. Lloyd.

\section{Anthropology and Archeology.}

John Murray.-Travels in Egypt and Mesopotamia in Search of Antiquities, 1886-1913, Dr. E. A. Wallis Budge, 2 vols., illustrated.

\section{Biology.}

A. and C. Black, Ltd.-A new edition of Studies in Fossil Botany, Dr. D. H. Scott, illustrated. Blackie and Son, Ltd.-Life and its Maintenance: A Symposium on Biological Problems of the Day, Prof. W. M. Bayliss, Dr. F. G. Hopkins, E: Margaret Hume, Prof. A. R. Cushny, K. J. J. Mackenzie, Dr. E. J. Russell, R. G. Stapledon, A. S. Horne, Prof. S. J. Hickson, A. G. Tansley, Lt.-Col. M. Flack, R. C. Maclean, Prof. F. W. Oliver, Dr. H. M. Vernon, and Prof. H. Kenwood. P. Blakiston's Son and Co. (Philadelphia).-A Classbook of Economic Entomology, Prof. W. Lochhead; Outlines of Economic Zoology, Prof. A. M. Reese; The Elements of Animal Biology, Prof. S. J. Holmes. The CamNO. 2574 . VOL. IO2 $\rceil$ 
bridge University Press.-Fossil Plants, Prof. A. C. Seward, vol. iv. (Cambridge Biological Series). Constable and Co., Ltd.-Animal Life and Human Prosress, edited by Prof. A. Dendy; Utility Ducks and Geese, J. W. Hurst, illustrated; Forests, Woods, and Trees in Relation to Hygiene, Prof. A. Henry, illustrated. The Epworth Press.-British Ferns and How to Identify Them, J. H. Crabtree, illustrated (The "How to Identify" Series). Hutchinson and Co.-Bird Behaviour," F. Finn, illustrated; Insect $\Lambda$ rtisans and their Work, E. Step, illustrated (Hutchinson's Nature Library). J. B. Lippincott Co.-The Chromosome Theory of Heredity, Prof. T. H. Morgan; Inbreeding and Outbreeding: Their Genetic and Sociological Significance, E. M. East and D. F. Jones; Pure Line Inheritance, $H$. S. Jennings; The Experimental Modification of the Process of Inheritance, Prof. R. Pearl; Localisation of Morphogenetic Substances in the Egg, Prof. I. G. Conklin; Tissue (iulture, R. G. Harrison; Permeability and Electrical Conductivity of Living Tissue, Prof. W. J. V. Osterhout; The Equilibrium between $\Lambda$ cids and Bases in Organism and Environment, Prof. L. J. Henderson; Chemical Bases of Growth, Prof. T. B. Robertson; Primitive Nervous System, G. II. Parker; Co-ordination in Locomotion, $\Lambda$. R. Moore (Monographs on Experimental Biology and General Physiology). Longmans and Co.-The Quantitative Method in Biology, Prof. J. MacLeod, and a new edition of British Birds, A. Thorburn, illustrated, vols. iii. and iv. Macmillan and Co., Ltd.-Botany of the I,iving Plant, Prof. F. O. Bower, illustrated; A Text-book of Embryology, vol. ii., The Non-mammalian Vertelorates, Prof. J. Graham Kerr, illustrated. John Murray. $-\Lambda$ new edition of Heredity, Prof. J. Arthur Thomson, illustrated. George Routledge and Sons, L.td., and Kegan Paul and Co., Ltd.-Timbers and their Uses, with a series of fine illustrations of grains of wood from new photographs; Germination, $\Lambda$. E. Baines, illustrated. Skeffington and Son, Ltd.-Birds and the War, H. S. Gladstone, illustrated. The University Tutorial Press, Ltd.- Text-book of Botany (Indian edition), J. M. Lowson, revised by Birbal Sahni. T. Fisher Unwin, I.td.-. Firewoods: Their Production and Fuel Values, A. D. Webster, illustrated; and a new edition of Instincts of the Herd in Peace and IVar, IV. Trotter.

\section{Chemistry.}

Baillic̀re, Tindall, and Cox.-Fats, Waxes, and Essential Oils, W. H. Simmons; Coal-tar Dyes and Intermediates, F. de Barry Barnett; Explosives, including Matches and Pyrotechnics, F. de Barry Barnett; The Industrial Giases, Dr. H. C. Greenwood; Silica and the Silicates, J. A. Audley; The Rare Earths and Metals, Dr. E. K. Rideal; The Iron Industry, A. E. Pratt; The Steel Industry, A. E. Pratt; Gasworks Products, H. H. Gray; Animal Proteids, H. G. Bennett; Organic Medicinal Chemicals, M. Barrowcliff and F. H. Carr; The Petroleum Industry, D. A. Sutherland; Wood and Cellulose, R. W. Sindall and W. Bacon; The Carbohydrates, Dr. S. Rideal; Rubber, Resins, Paints, and Varnishes, Dr. S. Rideal (Industrial Chemistry Series). Chapman and Hall, Ltd.-Food: Its Composition and Preparation, M. T. Dowe and J. D. Jameson; Outlines of Theorctical Chemistry, Dr. F. H. Getman; Chlorination of Water, J. Race. Constable and Co.. Ltd.-The Profession of Chemistry, R. B. Pilcher. H. Holt and Co. (New York).-College Text-book of Chemistry, Prof. IV. A. Noyes. I.ongmans and Co._Lead and its Compounds, Dr. J. A. Smythe; Liquid Fuel for Internal Combustion Engines, Sir Boverton Redwood, Bart., and Prof. J. S. S. Brame; Synthetic NO. 2574 , VOL. $\left.\mathrm{IO}_{2}\right]$
Colouring Matters: Sulphur Dyes, Prof. G. T. Morgan; Synthetic Colouring Matters: Vat Colours, Prof. J. F. Thorpe; Naphthalene, Prof. W.P. Wynne; Synthetic Colouring Matters Azo-Dyes, Dr. F. WV. Kay; Utilisation of Atmospheric Nitrogen: Synthetical Production of Ammonia and Nitric Acid, Prof. A. W. Crossley; Ccment, B. Blount; The Principles and Practice of Gas Purification, E. V. Evans; Refractories, Dr. J. W. Mellor; Ozone and Hydrogen Peroxide: Their Properties, Technical Production, and Applications, Dr. H. V. $\Lambda$. Briscoe; Industrial Applications of the Rarer Metals, W. G. Wagner and W. E. F. Powney; Cellulose-Silk, C. F. Cross; The Electric Arc in Chemical Industry, Dr. J. N. Pring; Organic Svnthetic Reactions: Their Application to Chemical Industry, Prof. J. B. Cohen; Synthetic Colouring Matters: Triphenylmethane Dyes, Prof. R. Robinson; Synthetic Colouring Matters: Anthracene and Allied Dyestuffs, F. W. Atack; Synthetio Colouring Matters: Acridine and Xanthene Dyestuffs, Dr. J. T. Hewitt; Synthetic Colouring Matters: Azine and Oxazine Dycstuffs, Dr. J. T. Hewitt; Synthetic Drugs: Local Anasthetics, Dr. IV. H. Hurtley and M. A. Whitelev; Plantation Rubber, G. S. White; Corrosion and Decay of Metals, Prof. C. H. Desch (Monographs on Industrial Chemistry); Boiler Chemistry, J. H. Paul; The Rare Earth Metals, Dr. J. F. Spencer; Chemical Affinity and Chemical Equilibrium, Dr. H. S. Taylor; and a new edition of Osmotic Pressure, Prof. A. Findlay (Monographs on Inorganic and Physical Chemistry); and a new edition of A System of Physical Chemistry, Prof. W. C. McC. Lewis, vol. iii., Quantum Theory (Text-boolss of Physical Chemistry). The University Tutorial Press, Ltd.-Senior Practical Chemistry, H. W. Bausor.

\section{ENGINEERING.}

Constable and Co., I,td.-Hot-bulb Oil Engines and Suitable Vessels, W. Pollock, illustrated; and new editions of Fuel, Water, and Gas Analysis for Steam Users, J. B. C. Kershaw; The Internal Combustion Engine: Being a Text-book on Gas, Oil, and Petrol Engines for the Use of Students and Engineers, H. E. Wimperis, illustrated; The Diesel Engine for Land and Marine Purposes, A. P. Chalkley, illustrated. Iongmans and Co.-Aeroplane Structures, A. J. S. Pippard and Capt. L. Pritchard, with a preface by L. Bairstow, illustrated: Naval Architects' Data, I. Mitchell, edited by F. L. Attwood; Efficient Boiler Management, with Notes on the Firing of Coal-fired Reheating Furnaces, C. F. Wade: Ships' Boats : Their Qualities, Construction. Equipment, and Launching Appliances, E. W. Blocksidge.

\section{Geography and Travel.}

T. Fisher Unwin, I.td.--In the Wilds of South America: Six Years of Exploration in Colombia, Venezuela, British Guiana, Peru, Bolivia, Argentina, Paraguay, and Brazil, Lieut. L. E. Miller, illustrated.

\section{Geology and Mineralogy.}

Chapman and Hall, I.td.-Popular Oil Geology, V. Ziegler; Handbook of Mineralogy, Blowpipe. Analysis, and Geometrical Crystallography, G. M. Butler. H. Holt and Co. (New York). - $\Lambda$ new edition of Physingraphy, Advanced Course, Prof. R. D. Salishury.

\section{Mathemiticat and Pinysical Sciences.}

George Allen and Unwin, Ltd.-Introduction to Mathematical Philosophy, Hon. B. Russell. Blackie and Son, I.td.-Applied Optics, vol. ii.. The Computation. of Optical Systems, being the "Handbuch der 
angewandten Optik" of Dr. A. Stenheil and Dr. E. Voit, translated and edited by J. Weir French. The Cambridge University Press.-Problems of Cosmogony and Stellar Dynamics, J. H. Jeans; Cambridge Astronomical Observations, vol. xxv. Cassell and Co. Ltd.- $A$ new edition of Electricity in the Service of Man, Dr. R. M. Walmsley, vol. ii., section ii. Chapman and Hall, Ltd.-Analytic Geometry, M. M. Roberts and J. T. Colpitts; A Handbook of Physics Measurements, E. S. Ferry, O. W. Silvey, G. W. Sherman, jun., and D. C.' Duncan, vol. i. Fundamental Measurements, Properties of Matter, and Optics, vol. ii. Vibratory Motion, Sound, Heat, Electricity, and Magnetism; Graphical and Mechanical Computation, Dr. J. Lipka; Mathematics for Engineers, W. N. Rose, part ii.; Graphic Dynamics, E. S. Andrews; and new editions of Descriptive Geometry, H. W. Miller, and Arithmetic for Engineers, C. B. Clapham. Constable and Co., L.td.-A new edition of The Propagation of Electric Currents in Telephone and Telegraph Conductors, Prof. J. A. Fleming. Longmans and Co.-Applied Aerodynamics, L. Bairstow, illustrated. Macmillan and Co., Ltd.-Elementary Mensuration, Constructive Plane Geometry, and Numerical Trigonometry, P. Goyen, and a new edition of The Theory of Heat, T. Preston, revised by J. R. Cotter, illustrated. The University Tutorial Press, Ltd.-Intermediate Text-book of Magnetism and Electricity, R. IV. Hutchinson; School Geometry (Matriculation Edition), A. G. Cracknell and W. P. Workman.

Medical Science.

Baillierc, Tindall, and Cox.-Injuries of the Head and Neck, Capt. L. Whale; The Heart: Past and Present, Dr. C. E. Lea; The Pituitary, Dr. W. Blair Bell. John Bale, Sons, and Danielsson, Ltd.-The Science and Art of Deep Breathing; Malaria and its Treatment in the Line and at the Base; Barbed Wire Disease; The Diseases of the New-born Child; The Essentials of Tropical Medicine; and new editions of The Surgical Treatment of Facial Neuralgia and The Prolongation of Life. A. and C. Black, Ltd.-Spas and Health Resorts of the British Isles: Their Mineral Waters, Climate, and the Treatment to be Obtained, Dr. T. D. Luke, illustrated; Cerebro-spinal Fever: The Etiology, Symptomatology, Diagnosis, and Treatment of Epidemic Cerebro-spinal Meningitis, Capt. C. Worster-Drought and Dr. A. M. Kennedy, illustrated; X-rays in General Practice: A Handbook for the General Practitioner and Student, Alice Vance Knox, with an introduction by Dr. R. Knox, illustrated (The Edinburgh Medical Series). Cassell and Co., Ltd.--The Story of English Public Health, Sir Malcolm Morris; The Housing Question, Dr. J. Robertson; The Welfare of the Infant and the Young Child, Prof. H. Scurfield; The Welfare of the School Child, Dr. H. J. Cates; The Welfare of the Expectant Mother, Dr. Mary Scharlieb; The Food Question, Dr. W. G. Savage (The Public Health Series); and a new edition of Elements of Surgical Diagnosis, Sir A. P. Gould and Dr. E. P. Gould, illustrated. Constable and Co., Ltd.-The Great War and the R.A.M.C., Lt.-Col. F. E. Brereton. W. Heinemann (Medical Books), Ltd.-Anaphylaxis and Antianaphylaxis, Dr. Bezredka, authorised English translation, edited and revised by Dr. S. R. Gloyne. Longmans and Co.-Tube Teeth and Porcelain Rods, J. Girdwood, illustrated. Macmillan and Co., Ltd.Dr. John Fothergill and His Friends: Chapters in Eighteenth-century Life, Dr. R. H. Fox, illustrated. Skeffington and Son, Ltd.-Medical Research and Human Welfare: A Record of Personal Experiences and Observations during a Professional Life of Fiftyseven Years, Dr. W. W. Keen.

NO. 2574 , VOL. IO2]

\section{Metallurgy.}

Constable and Co., Ltd.-A new edition of Malleable Cast Iron, S. J. Parsons.

\section{Meteorology.}

Constable and Co., Ltd.-A new edition of Forecasting Weather, Sir Napier Shaw, Methuen and Co., Ltd.-Weather Study for Schools, E. Stenhouse.

\section{Philosophy.}

The Cambridge University Press. Truth: An Essay in Moral Reconstruction, Sir C. Walston.

\section{TeChNology.}

Constable and Co., Ltd.-New editions of Glass Manufacture, Dr. W. Rosenhain; The Manufacture of Paper, R. W. Sindall; Wood Pulp, C. F. Cross, E. J. Bevan, and R. W. Sindall.

\section{Miscellaneous.}

Constable and Co., Ltd.--Dictionary of Scientific Instruments, prepared by the British Optical Instrument Manufacturers' Association, illustrated; The Claims of Labour and of Capital, W. R. Cooper. J. M. Dent and Sons, Ltd.-New Town: A Proposal in Agricultural, Industrial, Educational, Civic, and Social Reconstruction, edited for the "New Town Council" by W. H. Hughes. H. Holt and Co. (New York).-The World's Food Resources, Prof. J. Russell Smith. Macmillan and Co., Ltd.Annals of the Philosophical Club of the Royal Society, written from its Minute Books, Prof. T. G. Bonney. Methuen and Co., Ltd.-A Text-book of Hygiene for Training Colleges, M. Avery; School and Fireside Crafts, $\Lambda$. Macbeth, illustrated. John Murray. Education, Secondary and University, Sir F. G. Kenyon. George Routledge and Sons, Ltd., and Kegan Paul and Co., Ltd.-Routledge's Industrial Supremacy Books, dealing with agricultural machinery, commercial instruments, forestry, optical instruments, prepared foodstuffs, reproduction and utilisation of sound, shipbuilding, jig and tool making, testing machines, and watch and clock making; Handicrafts for the Handicapped, Dr. H. J. Buck and M. M. C. Buck, illustrated; The Science of Labour and its Organisation, Dr. J. Ioteyko; The Human Motor and the Scientific Foundations of Labour, Dr. J. Amar, with a preface by Prof. $H$. Le Chatelier, translated by E. Butterworth, the translation revised and edited by A. R. J. Ramsey, illustrated. T. Fisher Unwin, Ltd.-The Training of Youth: A Treatise on the Training of Adolescents, T. W. Berry.

\section{UNIVERSITY AND EDUCATIONAL INTELLIGENCE.}

CAMBrIDGE.-The Drapers' Company has resolved to continue its grant of roool. per annum towards the salaries of the professor of agriculture and the professor of agricultural botany for a period of ten years.

Mr. N. K. Adam, fellow of Trinity College, has been appointed to the Benn W. Levy research studentship in biochemistry for one year.

The Senate has approved a grace providing for the establishment of the degree of doctor of philosophy. The syndicate dealing with this question recommends that, subject to certain exemptions, candidates for the degree, before submitting a dissertation, must have pursued a course of research for not less than three years, and the Senate has determined that of this 